\title{
A Bakhtinian Reading of Joseph Conrad's Heart of Darkness
}

\author{
Ashraf Abu-Fares 8 (D) \\ University of Jordan, Amman, Jordan \\ Corresponding Author: Ashraf Abu-Fares, E-mail: ashraf.abufares@yahoo.com
}

\section{ARTICLE INFORMATION}

Received: June 08, 2021

Accepted: July 10, 2021

Volume: 1

Issue: 1

DOI: $10.32996 /$ ijts.2021.1.1.2

\section{KEYWORDS}

Conrad, Bakhtin, Heart of Darkness, polyphony, dialogism, imperialism

\section{ABSTRACT}

The purpose of this paper is to analyze Joseph Conrad's novel Heart of Darkness in line with Mikhail Bakhtin's theory of dialogism. Heart of Darkness is Conrad's novel written in 1899, in which Marlow narrates the story of the voyage he took part in up the Congo River into the Congo State in Africa. This paper analyses Conrad's text in relation to Bakhtin's concept of polyphony to show how Conrad represents the various voices and discourses in the narrative through a dialogic pattern that serves to illustrate the thematic concern of the novel. The paper highlights how the voices and discourses that exist both within Marlow's discourse as well in the other characters' discourses work together to formulate Conrad's stance on imperialism and his critique of its ideological manifestations.

\section{Introduction}

This paper analyses the narrative discourse in Conrad's novel Heart of Darkness to show Conrad's position towards imperialism. Hence, there is a commentary on the colonial-postcolonial power relations within this literary narrative. In addition, it is necessary to comment on language and linguistic discourse to show how their qualities are important in forming the events in the story. We can see that these elements embody devices that tackle the outlook on the "other" and give an image of how Conrad fundamentally builds up his polyphonic text.

One major concern in postcolonialist studies is to analyze critically the narrative discourse of literary texts representing the colonial experience. This type of study mainly sheds light on colonialist discourses that support colonization and colonial enterprises, especially with the claim of the 'civilizing mission' that the colonialist Europeans hold towards the colonized.

Therefore, one significant dimension in postcolonial studies is to link such literary texts that tackle the issue of colonization and the civilizing mission, of which Heart of Darkness is one illustration, to the wider cultural, social, and historical contexts they fit into. From this point, Mikhael Bakhtin's theory of dialogism becomes relevant, as it is effective in analyzing the discourse in a literary text and examining its relationship to the extra-textual aspects of the social and cultural aspects associated with it.

\section{Review of Related Literature}

Heart of Darkness narrates the story of the narrator's, Charlie Marlow, the journey from Europe to a part of a continent; Africa. It also tells the conflict between a manager of an ivory company and an ivory agent, Kurtz, both dominated by their greed and lack of humanity. These atrocious features morally debase these two men and lead to the latter's death. In this novel, Conrad comments on imperialism and racism, showing the dark side of Africa in parallel to "civilized" Europe, as he sees it.

There are many studies that deal with Conrad's novel, Heart of Darkness, from different angles. In Conrad in the Nineteenth Century, Ian Watt (1985) discusses the narrative devices Conrad uses in Heart of Darkness and Lord Jim. Watt argues that there are a number of impressionistic and symbolic narrative devices in these two texts playing a role in sustaining the meaning.

Ursula Lord (1998) discusses how Conrad's novels, such as Nostromo, Lord Jim, and Heart of Darkness, constitute "the epistemological crisis of the late nineteenth century" in their tension between the radical individual and community. Lord also

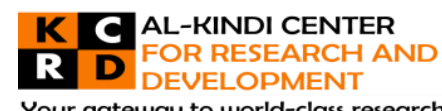

Your gateway to world-class research

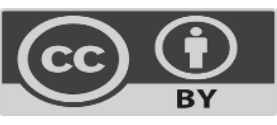

Published by Al-Kindi Center for Research and Development. Copyright (c) the author(s). This open access article is distributed under a Creative Commons Attribution (CC-BY) 4.0 license 
highlights Conrad's use of narrative strategies with an emphasis on the private, individual vision, as a contemporary collapse of a shared world view, and thus the "epistemological implications of narrative innovation" (146).

Many resources deal with Bakhtin's theory of dialogism and its implications. Lynne Pearce (1994) discusses this theory in her book Reading Dialogics. As far as Bakhtin's notion of polyphony is concerned, Pearce suggests that although Bakhtin proposes that Dostoevsky is the one who launched the polyphonic text in his novels, it is Bakhtin himself who is the original creator of this sort of novel because he suggests later that polyphony is "a tendency inherent in all novelistic discourse- Dostoevsky is simply an exemplary exponent of the form" (440).

Simon Dentith (1995), in Bakhtinian Thought: An Introductory Reader, explains the polyphonic aspect some novels might have. He observes that the polyphonic novel differs from the implicit "authoritarian" patterns of organization which maintain the final word for the narrator. The quality of independence which the characters gain in a polyphonic novel does not mean granting them this quality for being unable to interact with them; the authenticity of the polyphonic novel is so as it represents an engagement in which "the discourses of self and other interpenetrate each other" (42).

However, most of the studies that discuss Conrad's novel, Heart of Darkness, in relation to Bakhtin's theory of dialogism deal with other concepts in his theory, such as hetroglossia and the chronotope. There are few studies that analyze this text in terms of Bakhtin's notion of polyphony. Therefore, it is hoped that this study will contribute to the research done on Conrad's text to illuminate the role of polyphony in it and will add to our understanding of his fiction and literary style.

\section{Research Methodology}

The current research uses the qualitative, analytical method to achieve its objective. This method is suitable since the results are introduced in a descriptive manner and through a close analysis of the text under study. In addition, data is gathered from multiple resources, consisting of primary and secondary ones. The primary resources are comprised of Joseph Conrad's novel, Heart of Darkness. The secondary resources include books and scholarly articles.

\section{Discussion}

In his theory of dialogism, Bakhtin focuses on voices, and by this, his notions present many ways to study and analyze the voices that an author constructs or orchestrates in a text through showing their polyphonic and hetroglot dimensions. In The Dialogic Imagination, Bakhtin proposes that a speech utterance has elements of polyphony and hetroglossia as it "participates in the 'unitary language' (in its centripetal forces and tendencies) and at the same time partakes of social and historical heteroglossia (the centrifugal, stratifying forces)" (272). Hence, polyphony is a central notion in Bakhtin's theory and it is functional in how the text acquires its dialogic quality, while in some other cases, we have monologic texts that do not contain multiple voices. These texts cease to be polyphonic because the text is authoritarian and all the other voices are rendered within or under the author's voice and perspectives, while in the polyphonic novel, the voices are autonomous and present a view that could be as equal as the author's or even more significant than it.

Bakhtin's theory of dialogism helps to illuminate the various layers of voices in a novel. In Bakhtin's view, the novel is one of the best examples where we find voices included within one voice, in which the linguistic features help in uniquely telling the story. This makes the discourse in a novel 'novelistic', to use Bakhtin's term, and grants it its dialogic nature through the voices incorporated in its structure.

As a novel, Heart of Darkness addresses a challenging issue; the issue of imperialism and its motifs. The narrative is mainly constructed on two round trips which the narrator, Marlow, carries out conversely. The narrative is basically characterized by its polyphonic quality. It is formed through many scenes in dialogue, debates, and monologues. This makes the novel produce multiple voices that are important to present the overall story and its themes. Internal dialogues that some novels have, like Heart of Darkness, can be seen as a depiction of double-voiced narratives or a representation of polyphony. Many moments contain Marlow's internal monologues or private thoughts, as when he contemplates the dark journey he participated in. For instance, Marlow says:

It was the farthest point of navigation and the culminating point of my experience. It seemed somehow to throw a kind of light on everything about me-and into my thoughts. It was somber enough, too-and pitiful—not extraordinary in any way-not very clear either. No, not very clear. And yet it seemed to throw a kind of light. (Conrad, 7)

Heart of Darkness is a narrative that its author formulates to present his comment and critique regarding the evil of imperialism and the moral degradation of which one of its representatives, Kurtz, goes through as he becomes increasingly peculiar and atrocious in the darkness of the African Congo. However, the text of Heart of Darkness progresses with multiple voices other than Kurtz. Added to the unnamed narrator, Marlow is the basic narrator of the narrative and is one main voice having a more important 
role than that of Kurtz. Marlow transfers to a full-fledged character that goes in search of the meaning of his life and the core of truth away from pursuing dreams which may be perverted and substituted by nightmarish visions.

This novel of Conrad is a text which can be considered a literary product of the European colonial enterprise in the African Congo. Nevertheless, the narrative in this text has many polyphonic features. The tale involves a variety of voices and the narrative structure governing the progress of events has significant aspects. The narrative in Conrad's novel is constructed with two trips with departure and return. This method contributes to the overall pattern and rhythm of the narrative.

The tale apparently provides incidents and details about a European mission in which the destination is the continent of Africa. The European company assigns Marlow to inquire about Kurtz, the ivory chief agent at the Inner Station who stops sending ivory to the company. For this purpose, Marlow goes with other crew members on board the Nellie to investigate the situation. However, as Jacques Berthoud states, based on this experience Marlow encounters in the African Congo, Marlow perceives the deception that overwhelms the civilizing mission, and the journey turns in a different direction to a journey for Marlow himself within his own psyche and to question "how strong the hold of civilization is on its members" (45). In this sense, the incidents and details Marlow experiences can be seen as a psychological journey that he undergoes while carrying on his quest to find the truth about Kurtz and his situation.

Hence, in Heart of Darkness, it is the story of Kurtz that is retold to us by Marlow, as he narrates the events of his voyage to the African Congo to an audience; his European comrades on board the boat. Marlow does not go actually through the same experience as Kurtz. However, he is used by the author to provide his perception of imperialism, the colonial project, and the depiction of the "other". Thus, this journey Marlow goes through elicits a different tone and voice from him in order to present his understanding of the experiences he encounters and finds himself required to witness.

The journey around which the narrative structure is constructed and the flow of the tale brings up many insights regarding the moral dilemmas the protagonist, Kurtz, and the narrator of the tale go through. As a matter of fact, this can be linked to the historical context the novel revolves around, and how it is seen through colonial and postcolonial dimensions. In this manner, Heart of Darkness is a commentary on a historical reality related to the European colonization of the African Congo and a critique of the atrocious attitude of this colonization against the natives, accompanied by usurping their natural sources. Kurtz is a clear illustration of the colonialist agent who totally deteriorates when he fails to maintain his human entity as an individual. He becomes prey for the dark forces of the jungle that ultimately make him a monster sacrificing his ethics and any values linking him to civilization.

As far as Marlow is concerned, he almost takes a converse role from Kurtz. He does his best to reserve his moral balance and resist the debasement the jungle tempts a man to venture to. Nevertheless, there is a kind of dishonesty on the part of Marlow. Marlow insists on saving Kurtz through a lie that retains the bright image which Kurtz' Intended has for him. By this, Marlow does not adhere to the truth but does it with irony and uneasiness. Not only does he want to relief the Intended, but he also aims to save the image of the European civilization, of which Kurtz is one product:

I laid the ghost of his gifts at last with a lie," he began suddenly. "Girl! What? Did I mention a girl? Oh, she is out of it--completely. They-the women I mean--are out of it--should be out of it. We must help them to stay in that beautiful world of their own, lest ours gets worse. Oh, she had to be out of it. (Conrad 71)

Marlow almost whispers the truth about the situation in the African Congo only to himself. The nightmarish experience he encounters, represented mainly by the moral debasement of Kurtz, overwhelms and annoys him, and he attempts to evade this experience by questioning its reality. He makes his efforts to evade the test the jungle has for a civilized man to investigate his ability to control his instincts and primitive faculties. Marlow views his experiences in the jungle as bizarre and remote from reality. He says: "When you have to attend to things of that sort, to the mere incidents of the surface, the reality-the reality, I tell youfades. The inner truth is hidden-luckily, luckily. But I felt it all the same; I felt often its mysterious stillness watching me at my monkey tricks..." (Conrad, 49-50) Thus, he tries to survive his tragic knowledge while not admitting that he was self-deceived.

One major feature of polyphony, as Bakhtin sees it, is that it may be not totally embodied by several voices but through an individual voice that possesses a collective quality that creates a dialogic relationship among independent voices. Bakhtin suggests that the novel orchestrates all its themes, the totality of the world of objects and ideas depicted and expressed in it, using the social diversity of speech types and by the differing individual voices that flourish under such conditions (Bakhtin 263).

The narrative voice in Heart of Darkness is complex and contains several layers of voices within it. The narrative in this novel transfers from the polyphonic to the individual level, and then it returns to the launching start in Europe. The narrator recalls many personal and collective memories to comment on the hard times and experiences he and the other characters faced throughout their journey. 
In terms of the voices that exist in the narrative of Heart of Darkness, three main audible voices vibrate with implications and connotations; the unnamed narrator's, Marlow's, and Kurtz's voices. Conrad presents Marlow's and Kurtz's voices in relation to the inner moral dilemma experienced in different degrees and manners by both of them. However, the narrative in this novel entails several other voices, although part of these voices is ironically silenced and they do not have much significance or are not granted room to express themselves effectively as the voices of Kurtz and Marlow are granted.

The voices of the other white men whom Marlow encounters in the company or at the three stations up the River Congo play a role within the overall meaning the narrative tries to present, despite the narrow insights they have. For example, when Marlow inquires about the absurd shelling by the French vessel, only the accountant shows that he is part of the smart aspect of Europe, as he keeps a well-organized business record. Another example is that the Manager at the central Station rejects to accompany Marlow further through the River Congo since he loses hope to find Kurtz. Marlow comments on how he proclaims his opinion on the quest for Kurtz:

The manager came out. He did me the honor to take me under the arm and lead me aside. 'He is very low, very low,' he said. He considered it necessary to sigh but neglected to be consistently sorrowful. 'We have done all we could for him--haven't we? But there is no disguising the fact, Mr. Kurtz has done more harm than good to the Company. He did not see the time was not ripe for vigorous action. Cautiously, cautiously--that's my principle. (Conrad 93)

However, we see that the faceless, black African natives who spread throughout the African Congo remain silenced and voiceless. They are almost left outside the context of an encounter or experience with the white men who have come to invade the land. They are not given any room to speak themselves within the narrative, which is mostly taken control of by Marlow. They are just described as beastly and savage, or as mistresses and servants.

Therefore, the natives in Heart of Darkness do not have voices, and their consciousnesses are not revealed to us. They are only depicted as individuals who extinguish and die in silence while they retreat into the jungle. This shows that they are superficially depicted and marginalized by the narrator. Marlow's conscience and human perspective is the only dimension able to see them as humans after the White men mistreat them, especially Kurtz, who transforms them into pagans worshipping him as a god.

However, if we look carefully at how voices are rendered in the narrative, we see that it effectively serves the thematic concerns of the author. Conrad builds the polyphonic nature of the narrative in Heart of Darkness in this manner to depict the darkness and hollow side of the colonial heart or existence of the Europeans in Africa and show how the "other" or the natives are eliminated and manipulated by them in the course of this invasion process, which embodies all negative and atrocious aspects related to colonization. In addition, the narrative does not create a clear or defined account of the events and their reality. As Bakhtin proposes, "Even meanings born in dialogues of the remotest past will never be finally grasped once and for all, for they will always be renewed in a later dialogue" (Holquist 37). This may explain why Marlow keeps searching for the truth beyond the situation in the jungle, but he finds it inscrutable and indiscernible. Conrad aims to show this ambiguous and dark aspect of imperialism by making the narrative vague in this way.

One illustration for the ambiguity and difficulty to come to terms with the situation in the Congo, where Marlow finds himself trapped in is when Marlow says:

There were moments when one's past came back to one, as it will sometimes when you have not a moment to spare to yourself; but it came in the shape of an unrestful and noisy dream, remembered with wonder amongst the overwhelming realities of this strange world of plants, and water, and silence. (Conrad, 49)

In another speech, Marlow describes the vagueness and futility of the situation he finds himself in, and by this, he hints at imperialism and its dark side:

There were moments when one's past came back to one, as it will sometimes when you have not a moment to spare to yourself; but it came in the shape of an unrestful and noisy dream, remembered with wonder amongst the overwhelming realities of this strange world of plants, and water, and silence. And this stillness of life did not in the least resemble a peace. It was the stillness of an implacable force brooding over an inscrutable intention. It looked at you with a vengeful aspect. (Conrad, 49)

The last incidents and scenes in Heart of Darkness add to the depiction of the horrible side of the atmosphere and situation in the African Congo, providing the narrative with its utmost representation which Conrad intends to show as a symbol of darkness and desolation. However, Marlow goes back home and finalizes Kurtz's story with a 'lie' he devises for the sake of Kurtz's fiancée. He unfolded the reality of Kurtz for his Intended contrary to the truth. He leaves her to live with the deceitful fact regarding Kurtz's greatness and glory in Africa. As he says in the end, "[he] could not tell her. It would have been too dark — too dark altogether. . . ." (Conrad, 118) 
However, this action Marlow undertakes can also be seen as his own way to dismiss the hard time he went through and evade the horrible impact of the colonial experience and ambiguity of the situation he has been trapped in. Conversely, the truth about Kurtz and his reality is far from this. Marlow sees and perceives the opposite when he meets Kurtz in the dark cabin where Kurtz was dying. Marlow's description of Kurtz' status at these moments gives a significant image of the whole message the narrative attempts to express:

Anything approaching the change that came over his features I have never seen before, and hope never to see again. Oh, I wasn't touched. I was fascinated. [...] Did he live his life again in every detail of desire, temptation, and surrender during that supreme moment of complete knowledge? He cried in a whisper at some image, at some vision,--he cried out twice, a cry that was no more than a breath-"'The horror! The horror!' (Conrad 105)

With this diminishing voice of Kurtz inside the cabin and with his few words, Kurtz not only judges and categorizes his reality and the whole experience he went through, but also the reality of colonialism and its representatives from Europe and everywhere. This also contributes significantly to Marlow's full understanding of Kurtz's reality and his own reality at the same time.

\section{Conclusion}

As the analysis has shown, the narrative in Heart of Darkness is characterized by its polyphonic quality. It is formed in dialogue, debates, and monologues. This is functional in making the novel produce multiple voices that are significant to present the overall story and its themes. Furthermore, the internal dialogue in Heart of Darkness, represented through Marlow's private thoughts is important for contemplating the dark journey he participated in and can be seen as a representation of a double-voiced narrative or polyphony in the novel.

Moreover, the representation of the "other" in this novel is not totally 'monological', it has a polyphonic quality since there is a blend of several discourses that clash with each other and show the difficulty of coming up with a coherent image of the situation or experience described in the narrative. The narrative does not create a clear or defined account of the events and their reality. The depiction of the voices and the presentation of the narrative in this manner fundamentally contribute to sustaining the thematic concern which the author attempts at highlighting; that is, imperialism and its dark side.

Finally, all these aspects in the narrative are significant to embody Conrad's critique of imperialism and demonstrate the lack of reality and truth, which is incomprehensible and difficult to be grasped in such a situation the novel depicts. Thus, the meaning is ambivalent and ambiguous to some extent in the text. This shows that Conrad's text is not only linked to the social and political context it reflects, but also offers a narrative discourse with endless meanings that can be studied and analyzed from different dimensions, of which imperialism, racism, and gender are some examples.

\section{References}

[1] Bakhtin, Mikhail. Speech, Genres, and Other Late Essays, Translated by Vern W. McGee, Edited by Caryl Emerson and Michael Holquist. University of Texas Press, 1979.

[2] Bakhtin, M. The Dialogic Imagination: Four Essays, Edited by Michael Holquist, University of Texas Press, 1981.

[3] Berthoud, Jacques. Joseph Conrad: The Major Phase. Cambridge University Press, 1979.

[4] Conrad, Joseph. Heart of Darkness. York Press, 1994.

[5] Dentith, Simon. Bakhtinian Thought: An Introductory Reader. Routledge, 1995.

[6] Holquist, Michael. Dialogism: Bakhtin and his World. Routledge, 2002.

[7] Lord, Ursula. Solitude versus Solidarity in the Novels of Joseph Conrad: Political and Epistemological Implications of Narrative Innovation, McGill Queen's University Press, 1998.

[8] Morris, Pam. Ed. The Bakhtin Reader: Selected Writings of Bakhtin, Medvedev, and Voloshinov. Edward Arnold, 1994.

[9] Pearce, Lynne. Reading Dialogics. Edward Arnold, 1994.

[10] Watt, Ian. Conrad in the Nineteenth Century. Chatto \& Windus. Ltd, 1985. 